OPNAME VAN TEVREDENHEID VAN B.CUR.- FINALEJAARSTUDENTE AAN DIE RANDSE AFRIKAANSE UNIVERSITEIT

\title{
A M Lemmer
}

B.Cur.; GV

B.Cur.-student, Departement Verpleegkunde, Randse Afrikaanse Universiteit

\section{K Jooste}

D.Litt et Phil;GV

Mede-Professor, Departement Verpleegkunde, Randse Afrikaanse Universiteit

Korresponderende outeur: kjo@edcur.rau.ac.za

\author{
AC Botes (wyle) \\ D.Cur; GV \\ Professor, Departement Verpleegkunde, Randse Afrikaanse Universiteit
}

Sleutelwoorde: Studente-/verbruikerstevredenheid; kwaliteitversekering; universiteitsopleiding; opvoedkundige programme

Keywords: Student/consumer satisfaction; quality assurance; university education; education programmes

\section{OPSOMMING}

Die doel van die studie was om die B.Cur.-vierdejaarstudente aan die Randse Afrikaanse Universiteit (RAU), van die jaar 2001, se tevredenheid ten opsigte van hulle B.Cur.-program te bepaal. Om die doelstelling te bereik, was die volgende doelwitte relevant, naamlik:

- 'n Beskrywing van die vlakke van tevredenheid van die B.Cur.-vierdejaarstudente aan die RAU.

- ' $n$ Beskrywing van die verhouding tussen tevredenheid van die studente en hoe belangrik hulle sekere aspekte in die struktuur, prosesse en uitkomste van die universiteitsomgewing beskou.

Die navorsingstudie was binne die konteks van die RAU uitgevoer. Die B.Cur.-kurrikulum is in 1998 gewysig. Dit is 'n graadkursus wat vier jaar duur, en tot registrasie as verpleegkundige (algemene, psigiatriese en gemeenskapsverpleegkunde) en vroedvrou lei. Die vierdejaarstudente van 2001 was die eerste groep wat die hersiene kurrikulum voltooi het. Dit was dus om hierdie rede sinvol om die studente-tevredenheid te evalueer. Ten einde die doelstelling te bereik is ' $n$ kwantitatiewe opname-ontwerp gebruik. Die totale populasie $(N=18)$ van die B.Cur.-vierdejaargroep is gebruik. 'n Bestaande instrument wat deur die RAU se Sentrum vir Hoëronderwysstudies, in die jaar 2000 ontwikkel is, is gebruik. Die meetinstrument was in die vorm van ' $n$ Likertskaal wat op 'n numeriese waarde van 1 tot 7 gemeet het. Twee aspekte is aangeraak: die studente se metings van hulle vlakke van tevredenheid met elke item en hulle evaluering van die belangrikheid van elke item vir studente. Die navorser het die vraelys persoonlik aan elke student uitgedeel. Al 18 vraelyste wat uitgedeel was, is terugontvang. ' $n$ Statistiese konsultant was behulpsaam met die beskrywende statistiek (frekwensies, persentasies, korrelasies, gemiddeldes en standaardafwykings) wat gebruik is om die data te ontleed en te beskryf. Die bevindings van die navorsing dui op 'n hoë vlak van tevredenheid van die studente.

\section{ABSTRACT}

The purpose of this study was to determine the satisfaction of the B Cur fourth-year students (2001) at the Rand Afrikaans University (RAU), in terms of their B Cur programme. The following objectives were important for achieving this goal:

- A description of the levels of satisfaction of the B Cur fourth year students at the RAU. 
- A description of the relationships between the satisfaction of the students and their rated importance of aspects like structure, process and outcomes of the university environment.

This research study was carried out within the context of the RAU. The B Cur curriculum was modified in 1998. This is a four year degree course which leads to registration as a nurse (general, psychiatric and community) and midwife. The fourth-year students of 2001 were the first group to complete their studies with the revised curriculum. Thus it was important to evaluate student satisfaction. In order to achieve the purpose of the study, a quantitative survey design was used. The total population $(N=18)$ of the $B$ Cur fourth-year group participated in the survey. An existing instrument (developed by the RAU's Centre for Higher Education Studies in 2000) was used to gather data. This measuring instrument comprises a Likert scale which measures numerical values from 1 to 7 . Two important aspects were addressed: the students' ratings of their levels of satisfaction with each item and the evaluation of the importance of each item to students. The researcher personally handed the questionnaires to each student. All 18 questionnaires handed out, were returned to the researcher. With the help of a statistics consultant, descriptive statistics (frequency, percentages, correlations, standard deviation and mean) were used to analyse and describe the data. The findings of the research indicate a high level of students' satisfaction with their studies.

\section{INLEIDING}

Die doel van die studie was om die B.Cur.vierdejaarstudente aan die Randse Afrikaanse Universiteit (RAU) van die jaar 2001 se tevredenheid ten opsigte van hulle B.Cur.-program te bepaal.

Die navorsingstudie is binne die konteks van die RAU uitgevoer. Die B.Cur.-kurrikulum is in 1998 gewysig. Dit is ' $n$ graadkursus wat vier jaar duur en tot registrasie as verpleegkundige (algemene, psigiatriese en gemeenskapsverpleegkunde) en vroedvrou lei. Dit sluit teoretiese en praktiese komponente, wat die studente in goedgekeurde kliniese fasiliteite uitvoer, in. Die vierdejaarstudente van 2001 was die eerste groep wat die hersiene kurrikulum voltooi het. Dit was dus om hierdie rede sinvol om die studente-tevredenheid te evalueer.

In hierdie studie is studente-tevredenheid die sentrale konsep. Studente-tevredenheid in die hoëronderwyskonteks, is die mate waarin daar aan studente se doelwitte en verwagtinge voldoen is. Dit verwys ook na die bruikbaarheid en die mate van vervulling van alle strukture, prosesse en uitkomste in die student se leeromgewing (Fontenot, Behara \& Gresham, 1994:73; Oliver, 1997:13).

Studente-tevredenheid hou egter grootliks verband met kwaliteitversekering in hoëronderwysinstellings. Kwaliteit handel oor die vraag: "Doen ons die regte dinge reg?" (Vroeijenstein, 2001:5). Muller (1998:247) beskryf relevante wyses waarop kwaliteit geëvalueer en verseker kan word. Dit sluit selfevaluering, indirekte observasie, dokumentanalise en -ouditering, portuurgroepevaluasie en studente-tevredenheid in. Studente-tevredenheid is die fokuspunt van hierdie studie. Die wyse waarop kwaliteit geëvalueer word, is binne die nasionale onderwyskonteks en die verpleegberoepskonteks (beroepskonteks en gesondheidsdienskonteks) ingedeel.

Studente-tevredenheid word binne verskillende kontekste in hierdie studie bespreek. Die Nasionale Plan vir Hoër Onderwys en SAKO (Suid-Afrikaanse Kwalifikasie-Owerheid) val in die nasionale onderwyskonteks, en is voorskriftelik van wat kwaliteit in 'n hoëronderwysinstelling behoort te wees. Die woord "gehalte", oftewel kwaliteit, word 64 keer in die Nasionale Plan genoem. Een van die Nasionale Plan se prioriteite is: "To link improvements in efficiency to improvements in quality" (Department of Higher and Further Education, 2001:16).

Binne die beroepskonteks speel die Suid-Afrikaanse Raad vir Verpleging (SARV) ' $n$ belangrike rol in die regulering en stel van eise in die professie. Dit is nodig sodat alle verpleegonderwysinstellings oor riglyne beskik wat hulle moet volg om kwaliteit te verseker.

Binne die gesondheidsdienskonteks word eise onderskryf waaraan die verpleegkundige in die praktyk moet voldoen. Bergman se model vir professionele aanspreeklikheid (Muller, 2001:56) is as agtergrond 
gebruik om hierdie konteks te verduidelik.

In hierdie studie word die sisteemteorie (Lilienfeld, 1978:18) as teoretiese vertrekpunt gebruik.

\section{PROBLEEMSTELLING EN NAVORSINGS- VRAAG}

Vanuit die voorafgaande inleiding blyk dit belangrik te wees dat kwaliteit aan ' $n$ hoëronderwysinstelling verseker word.

Soos reeds gemeld, was die finalejaarstudente van 2001, aan die RAU, die eerste groep studente wat met die nuwe B.Cur.-program afstudeer het. Die kwaliteit van die program was derhalwe nog nie geëvalueer nie.

Uit die probleemstelling blyk die volgende navorsingsvraag belangrik te wees: Hoe tevrede was die B.Cur.-finalejaarstudente van 2001 met die B.Cur.program en die universiteitsmilieu waarin die program aangebied word?

\section{DOELSTELLING EN DOELWITTE}

Die doel van hierdie navorsingsverslag is om die studente-tevredenheid van die B.Cur. vierdejaarstudente van die jaar 2001 aan die RAU te evalueer.

Om die doelstelling te bereik is die volgende doelwitte relevant, naamlik:

- 'n Beskrywing van die vlakke van tevredenheid van die B.Cur.-vierdejaarstudente aan die RAU.

- 'n Beskrywing van die verband tussen tevredenheid van die studente en hoe belangrik hulle sekere aspekte in die struktuur, prosesse en uitkomste van die universiteitsomgewing beskou.

\section{NAVORSINGSONTWERP EN -METODES}

Ten einde die doelstelling te bereik, is ' $n$ kwantitatiewe opname-ontwerp gebruik (Brink, 1999:109).

\section{Populasie en steekproefneming}

Die totale populasie van die B.Cur.-vierdejaargroep was gebruik $(N=18)$. Daar was sewentien vroulike studente en een manlike student. Daar was een student uit die swart bevolkingsgroep, twee studente uit die kleurlinggroep en vyftien studente uit die blanke bevolkingsgroep. Sestien van die studente was Afrikaanssprekend en die oorblywende twee studente was Engelssprekend.

\section{Data-insamelingsinstrument, geldigheid en betroubaarheid}

'n Bestaande instrument, wat deur die RAU se Sentrum vir Hoëronderwysstudies in die jaar 2000 ontwikkel is, is gebruik. Die meetinstrument is in die vorm van ' $n$ Likert-skaal (Brink, 1999:160) wat op 'n numeriese waarde van 1 tot 7 meet. Twee aspekte word aangeraak, naamlik hoe tevrede die student met die bepaalde item is en hoe belangrik hierdie item vir die student is.

Die meetinstrument bevat siggeldigheid, aangesien dit deur ' $n$ paneel van kundiges van die RAU se Kwaliteitsversekeringskomitee geëvalueer is. Dit bevat ook inhoudsgeldigheid op grond van konseptualisering binne hierdie studie (Brink, 1999:124).

Hierdie instrument is ' $n$ geldige en betroubare getoetse instrument wat op ' $n$ daaglikse basis binne die Universiteitsraamwerk sedert 2001 vir die evaluering van tevredenheid van studente met onderrigeffektiwiteit, in alle vakgebiede aangewend word. Data wat oor ' $n$ periode van 4 jaar versamel is, is in 2001 in ' $n$ itemanalise (Gulliksen Indeks) gebruik wat tot ' $n$ betroubaarheidskoeffisiënt van 0,966 gelei het. ' $n$ Ontdekkende faktoranalise is op die data uitgevoer en vier faktore is roteer deur gebruikmaking van ' $n$ skuinsrotasie. Die vier faktore het ooreengekom met die vier hoofkonsepte van onderrigeffektiwiteit wat die hipotese van die studie moes meet. Konstrukgeldigheid van die instrument is dus sodoende verseker.

Die basiese inhoud van die meetinstrument lyk soos volg:

- Inleiding en instruksies

- Biografiese inligting

- Kursusorganisering en assessering

- Kommunikasie van inligting

- Organisasie van die kursus

- Werklading en assessering

- Uitkomste van studie

- Onderrig en leer 
- Dosente

- Onderrigsessies (lesings/seminare)

- Individuele onderrig (tutor met een of twee studente)

- Praktiese sessies (laboratorium/ateljee/ werkswinkels)

- Werkervaring

- Die biblioteek

- Rekenaarfasiliteite

- Studentedienste

- Die universiteitsomgewing

- Studentesentrum

- Studenteraad en sosiale lewe

- Finansiële aangeleenthede

- Selfontwikkeling

- Finale evaluering

\section{Data-insamelingsprosedure}

Die navorser het elke vraelys persoonlik aan al die studente uitgedeel. Die navorser het elke student ongeveer drie weke tyd gegee om die vraelys te voltooi. Daarna het die navorser weer elke voltooide vraelys persoonlik van elke deelnemer ontvang. Al 18 vraelyste wat uitgedeel is, is terugontvang. Die navorser het sodoende die mortaliteitseffek oorkom (Brink, 1999:107). Al die deelnemers het die belangrikheid van die studie besef en het nie tydens die datainsamelingsproses hul deelname beëindig nie.

\section{Data-analise}

'n Statistiese konsultant was behulpsaam met die volgende beskrywende statistieke:

- Frekwensies en persentasies by biografiese inligting en die studente se vlakke van tevredenheid.

Die volgende is gebruik om die verband tussen tevredenheid en belangrikheid van elke item te bepaal:

- Korrelasie

- Beduidenheid

- Gemiddeldes

- Standaardafwykings

- Tekortontledings (gap analyses)

\section{ETIESE MAATREËLS}

toegepas:

- Reg tot privaatheid, konfidensialiteit en anonimiteit. Om die privaatheid van die deelnemers te beskerm en konfidensialiteit te handhaaf is alle antwoordblaaie na afloop van die navorsing vernietig (RAU, 2001:20). Data was op so 'n wyse gekommunikeer dat dit nie aan ' $\mathrm{n}$ bepaalde deelnemer gekoppel kon word nie.

- Reg tot vryheid van keuse, uitdrukking en toegang tot informasie. Al die deelnemers is telefonies om hul toestemming gevra en was onder geen omstandighede gedwing om aan die studie deel te neem nie. Hierbenewens is alle navrae van die deelnemers telefonies beantwoord en die doel en ander voordele van die studie is aan die deelnemers verduidelik.

\section{KONSEPTUALISERING}

Figuur 1 beskryf die konseptuele raamwerk van die studie. Die teoretiese vertrekpunt vir hierdie studie is die sisteemteorie (Lilienfeld, 1978:18). Volgens Kozier, Erb, Blais en Wilkinson (1995:277) is die individu in interaksie met sy omgewing. Konstante insette (stimuli) in die sisteem en terugvoering onderhou die sisteem in 'n staat van dinamiese ekwilibrium.

In ' $n$ hoëronderwysinstelling moet al die verskillende komponente saamwerk om kwaliteit te verseker. Een komponent wat nie ten volle funksioneer nie kan die kwaliteitsversekering van die hele hoëronderwysinstelling benadeel. Enige sisteem het strukture, prosesse en uitkomste, en op grond van die uitkomskriteria word terugvoering oor die struktuur en prosesdimensies van die sisteem gegee.

As deel van konseptualisering word die sentrale konsepte van die studie eerstens verduidelik. Tweedens word die struktuur, proses en uitkomste van hoëronderwysinstellings beskryf om inhoudsgeldigheid aan die vraelys (meetinstrument) te verleen. Figuur 1 stel die konseptuele raamwerke van die studie grafies voor. 


\section{SARV ( Suid-Afrikaanse Raad op Verpleging)}

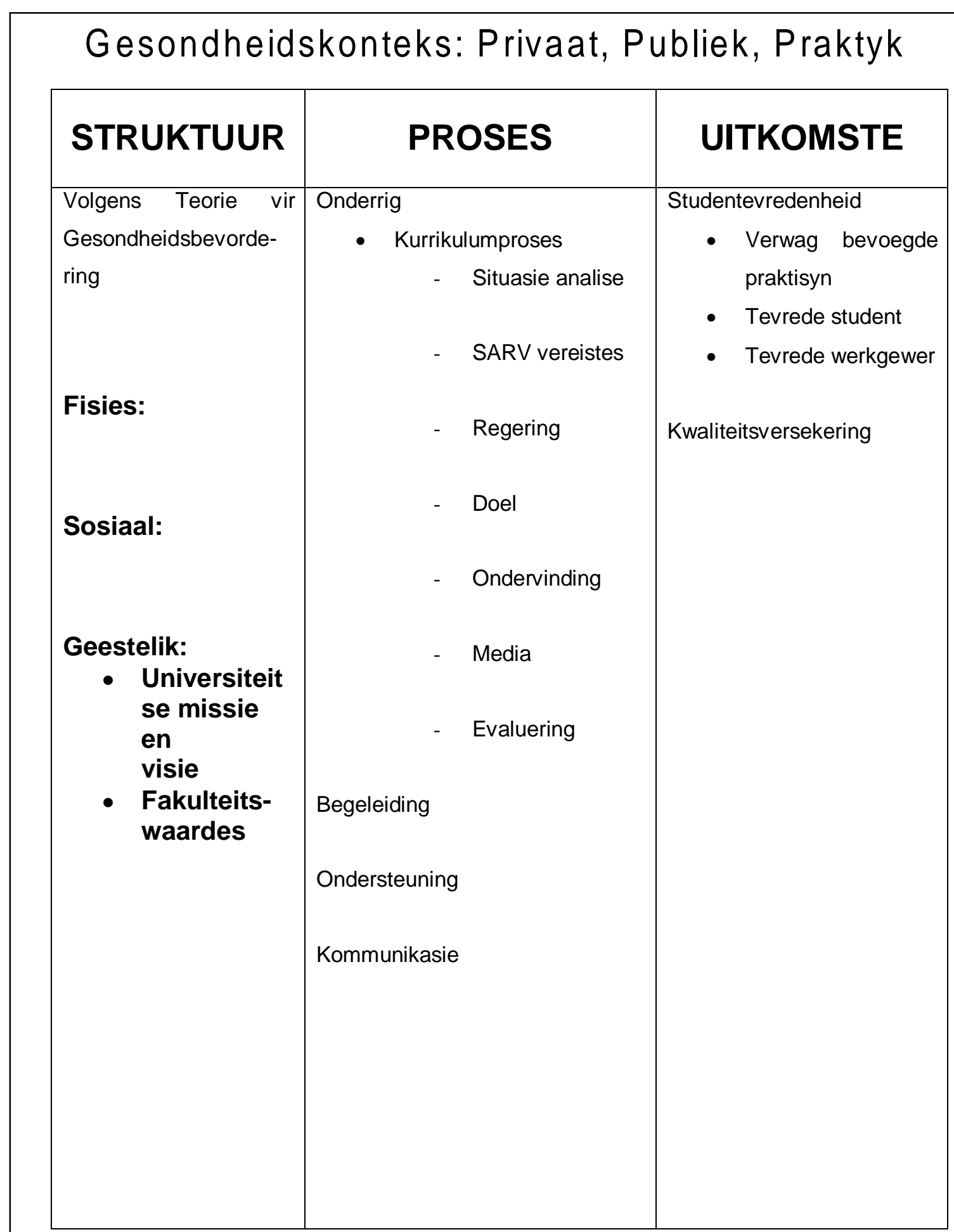

\section{NASIONALE PLAN}




\section{Verduideliking van sentrale konsepte}

Die sentrale konsepte van hierdie studie handel eerstens oor studente-tevredenheid. Studentetevredenheid hou verband met kwaliteitsversekering, en om dié rede moet kwaliteitsversekering ook verduidelik word.

\section{Kwaliteit}

Kwaliteit handel hoofsaaklik oor die vraag: "Doen ons die regte dinge reg?" (Vroeijenstein, 2001:5). Muller (1998:237) sluit hierby aan deur kwaliteit met uitnemendheid te verbind. Aangepas uit Muller, is kwaliteit die eienskappe van uitnemendheid, en hierdie eienskappe van uitnemendheid kry gestalte op verskillende wyses, deur middel van die verskillende rolspelers in die hoëronderwysinstelling, naamlik die student, bestuur en dosent (Vroeijenstein, 2001:6).

'n Student verwag goeie studiegeleenthede vir persoonlike ontwikkeling. Studente verwag ook goeie voorbereiding vir hulle posisie eendag in die samelewing as professionele praktisyns. Volgens Vroeijenstein (2001:7) is die dosente in ' $n$ hoëronderwysinstelling se siening van kwaliteitsversekering die lewering van onafhanklike graduandi en hoëkwaliteit-onderrig. So ook wil die toekomstige werkgewers goed opgeleide, onafhanklike en professionele werkers in diens neem.

Die wyses waarop kwaliteit verseker kan word is deur middel van selfevaluering, indirekte observasie, dokumentanalise, ouditering en portuurgroepevaluasie van studente-tevredenheid. Bogenoemde wyses van evaluering word soos volg beskryf, soos aangepas uit Muller (1998:247):

- Selfevaluasie: Selfevaluering verwys na die rolspelers se eie evaluasie van hoe goed of hoe sleg hulle aan die gestelde standaarde voldoen. Hulle moet hulself op hulle eie vlak van bevoegdheid evalueer, en die uitslae van hierdie evaluasie bly die betrokke rolspelers se verantwoordelikheid.

- Indirekte observasie: Die studente wat by 'n betrokke dosent klas kry, maak deurentyd indirekte observasies van die dosent se onderrigmetodes en -vaardighede. Die dosent word dan deur die student geëvalueer met behulp van formele evalueringsessies.
- Dokumentanalise en ouditering: Die inhoud van relevante dokumente binne die hoëronderwysinstelling, byvoorbeeld die studiehandleidings, kurrikulumdokumente, toetse en eksamenvraestelle word bestudeer om te bepaal of dit aan die gestelde standaarde en kriteria vir gehalte-onderrig voldoen.

- Portuurgroepevaluasie: Dit is wanneer ' $n$ kollega van die betrokke dosent, byvoorbeeld die studiehandleidings van die betrokke dosent evalueer om te bepaal of dit aan die gestelde standaarde en vereistes voldoen.

- Studente-tevredenheid: Met studentetevredenheid word die student se siening van die kwaliteit van die onderrig ondersoek, gewoonlik met behulp van ' $n$ vraelys of ' $n$ onderhoud. Die studente evalueer die kwaliteit, na aanleiding van die ondersteunende strukture in die instelling, die prosesse van onderrig en die uitkomste van leer wat deel uitmaak van studente-tevredenheid. Hierdie studie fokus op studente-tevredenheid as deel van kwaliteitsversekering.

\section{Studente-tevredenheid}

Om studente-tevredenheid te kan verduidelik, moet die navorser eers verbruikerstevredenheid verduidelik. Die volgende definisies van verbruikerstevredenheid word uitgelig:

Tevredenheid is die verbruiker se vervullingsreaksie. Dit is ' $n$ oordeel dat ' $n$ produk of diens wat voorsien word ' $\mathrm{n}$ vervullende vlak van bruikbaarheid bevat, insluitend onder- of oorvervulling (Oliver, 1997:13). Tevredenheid kan verbind word aan ' $n$ individuele strewe na doelwitbereiking deur die verbruik van produkte of dienste (Oliver, 1997:10). Verbruikerstevredenheid word baie selde gebaseer op kontak met een persoon of aspek van 'n maatskappy. Verbruikerstevredenheid is ' $n$ meervlakkige proses wat beïnvloed word deur dienslewering aan verbruikers asook die produk ter sprake (Fontenot, Behara \& Gresham, 1994:73).

In die lig van bogenoemde definisies kan studentetevredenheid soos volg gedefinieer word: Studentetevredenheid in die hoëronderwyskonteks, is die mate waartoe daar aan die student se doelwitte en verwagtinge voldoen is. Dit verwys ook na die bruikbaarheid en die mate van vervulling van alle 
strukture, prosesse en uitkomste in die student se omgewing (Fontenot et al. 1994:73; Oliver, 1997:13).

\section{Struktuur in hoëronderwysinstellings}

Die navorser het die struktuur in drie afdelings onderverdeel: fisiese, sosiale en geestelike dimensies. Volgens die RAU se Departement Verpleegkunde se Teorie vir Gesondheidsbevordering (2001:7) is die mens ' $n$ holistiese wese wat voortdurend in interaksie met sy omgewing is. Die omgewing bestaan uit die interne en eksterne omgewing. Die eksterne omgewing bestaan uit die fisiese, sosiale en geestelike dimensies.

Die fisiese dimensie verwys na fisiese en chemiese agente/strukture in die eksterne omgewing van die individu/gesin/groep/gemeenskap. Die fisiese dimensie in die leeromgewing van die student sluit die volgende in:

- Die biblioteek

- Rekenaarfasiliteite

- Die universiteitsomgewing en studentesentrum

- Die studenteraad en sosiale lewe

- Finansies

Die sosiale dimensie verwys na die menslike hulpbronne in die eksterne omgewing van die individu/ gesin/groep/gemeenskap. Die sosiale dimensie in die leeromgewing van die student sluit die volgende in:

- Dosente en onderrig en leer

- Studentedienste

Die geestelike dimensie verwys na waardes en religieuse aspekte in die eksterne omgewing van die individu/gesin/groep/gemeenskap. Dit sluit die missie en visie van die instelling in.

\section{Proses in hoëronderwysinstellings}

"Proses is ' $n$ aantal dade of progressiewe veranderinge na 'n verwagte eindpunt of doelwit" (Bevis, 1978:8). Die aspekte wat onder die proses in hoëronderwysinstellings val, is kursusorganisering, assessering en die kurrikula.

\section{Uitkomste in hoëronderwysinstellings}

"Outcomes are defined as the result of learning processes and refer to knowledge, skills, attitudes and values within a particular context" (SAQA, 1997:6). In die Suid-Afrikaanse konteks is uitkoms-gebaseerde onderrig ' $n$ baie belangrike konsep. SAKO (SuidAfrikaanse Kwalifikasie-owerheid) sluit ook baie definitiewe kritiese uitkomste in, onder andere:

- Probleemoplossing

- Spanfunksionering

- Selfverantwoordelikhede

- Navorsingsvaardigheid

- Kommunikasievaardighede

- Tegnologie en geletterdheid

- Ontwikkeling van makrovisie

- Leerstrategieë

- Burgerskap

- Kulturele en estetiese sensitiwiteit

- Loopbaanvaardighede en entrepreneurskap

Dit sluit aan by die leeruitkomste wat die Departement Verpleegkunde (2002) aan die B.Cur.-studente stel, naamlik: "Die leerder demonstreer die vermoë om as onafhanklike, beginner- en omvattende verpleegkundige (algemeen, psigiatrie, gemeenskaps), en vroedvrou te praktiseer in die beraming, diagnosering, beplanning, implementering en evaluering van gesondheidsorg aan die individu, gesin, groep en gemeenskap as lid van die gesondheidspan, binne die eties-wetlike raamwerk van verpleging in Suid-Afrika."

By ' $n$ hoëronderwysinstelling is kwaliteitonderrig ' $n$ vereiste, anders sal die uitkomste nooit bereik word nie en studente-tevredenheid sal nooit bewerkstellig word nie.

\section{BEVINDINGE EN GEVOLGTREKKINGS}

Die bevindinge en gevolgtrekkinge is gebaseer op die doelwitte wat vir die studie gestel is, naamlik

- die beskrywing van die vlakke van tevredenheid van die B.Cur.-vierdejaarstudente aan die RAU; en

- die beskrywing van die verband tussen die tevredenheid van die studente en hoe belangrik hulle sekere aspekte in die struktuur, prosesse en uitkomste van die universiteitsomgewing beskou. 
Vlakke van tevredenheid ten opsigte van die B.Cur.- kursus

Die persentasies strek van 0 - 100\%. Tabel 1 dui aan dat die laagste persentasie van studente-tevredenheid ten opsigte van die B.Cur.-kursus $60 \%$ is. Vier studente van die totale B.Cur.-vierdejaarpopulasie was $100 \%$ tevrede met die kursus. Dit is ' $n$ aanduiding dat studente-tevredenheid in hierdie opsig baie goed is.

Tabel 1: B.Cur.-kursus: Vlakke van tevredenheid

\begin{tabular}{|l|l|l|l|}
\hline Vlak van tevredenheid in \% & Persentasie & Frekwensie & Kumulatiewe frekwensie \\
\hline 60 & 1 & 5.6 & 1 \\
\hline 65 & 1 & 5.6 & 2 \\
\hline 70 & 1 & 5.6 & 3 \\
\hline 75 & 1 & 5.6 & 4 \\
\hline 80 & 3 & 16.7 & 7 \\
\hline 85 & 2 & 11.1 & 9 \\
\hline 90 & 2 & 11.1 & 11 \\
\hline 95 & 1 & 5.6 & 12 \\
\hline 98 & 1 & 5.6 & 13 \\
\hline 100 & 4 & 22.2 & 17 \\
\hline TOTAAL & $\mathbf{1 7}$ & $\mathbf{9 4 . 4}$ & \\
\hline Verlore respondent & 1 & 5.6 & \\
\hline
\end{tabular}

\section{Vlakke van tevredenheid ten opsigte van die Fakulteit en Departement Verpleegkunde}

Die persentasies strek weer eens van $0-100 \%$. Die laagste persentasie van tevredenheid van die studente ten opsigte van die fakulteit/departement was $60 \%$. Drie studente van die totale populasie het aangedui dat hulle $100 \%$ tevrede was met die fakulteit/departement, soos aangedui in Tabel 2 . Vier van die studente was $90 \%$ tevrede. Al bogenoemde data dui op ' $n$ hoë vlak van tevredenheid onder die B.Cur.-vierdejaarstudente. Die gevolgtrekking wat gemaak kan word is dat die studente ' $n$ tevrede vlak van bruikbaarheid geniet het (Oliver, 1997:13). (Tabel 2 is op die volgende bladsy).

\section{Vlakke van tevredenheid ten opsigte van die RAU-bestuur}

Die laagste persentasie van tevredenheid ten opsigte van die RAU-bestuur was weer eens $60 \%$. Volgens tabel 3 was vier studente $90 \%$ tevrede en slegs een student was hierdie keer $100 \%$. Studente-tevredenheid was dus nie net op een persoon of aspek van 'n maatskappy gebaseer nie (Fontenot et al. 1994:73). (Tabel 3 is op die volgende bladsy).

\section{Vlakke van tevredenheid ten opsigte van die RAU as geheel}

Volgens Tabel 4 is die laagste persentasie van studente-tevredenheid ten opsigte van RAU as geheel $70 \%$. Vyf studente was $80 \%$ tevrede met die RAU as geheel en 4 studente was $90 \%$ tevrede met die RAU as geheel. Dit dui daarop dat die studente ' $n$ hoë vlak van algehele tevredenheid ervaar want die proses van tevredenheid is veeldimensioneel. (Fontenot et al. 1994:73). (Tabel 4 is op bladsy 57). 
Tabel 2: Fakulteit en Departement Verpleegkunde: Vlakke van tevredenheid

\begin{tabular}{|l|l|l|l|}
\hline Vlak van tevredenheid in \% & Frekwensie & Frekwensie & Kumulatiewe frekwensie \\
\hline 60 & 1 & 5.6 & 1 \\
\hline 65 & 1 & 5.6 & 2 \\
\hline 75 & 2 & 11.1 & 4 \\
\hline 80 & 2 & 11.1 & 6 \\
\hline 85 & 1 & 5.6 & 7 \\
\hline 89 & 1 & 5.6 & 8 \\
\hline 90 & 4 & 22.2 & 12 \\
\hline 95 & 1 & 5.6 & 13 \\
\hline 98 & 1 & 5.6 & 14 \\
\hline 100 & 3 & 16.7 & 17 \\
\hline Totaal & 17 & 94.4 & \\
\hline Vermiste respondent & 1 & 5.6 & \\
\hline
\end{tabular}

Tabel 3: RAU-Bestuur: Vlakke van tevredenheid

\begin{tabular}{|l|l|l|l|}
\hline Vlak van tevredenheid in \% & Frekwensie & Persentasie & Kumulatiewe frekwensie \\
\hline 60 & 1 & 5.6 & 1 \\
\hline 65 & 2 & 11.1 & 3 \\
\hline 70 & 3 & 16.7 & 6 \\
\hline 79 & 1 & 5.6 & 7 \\
\hline 80 & 3 & 16.7 & 10 \\
\hline 85 & 1 & 5.6 & 11 \\
\hline 90 & 4 & 22.2 & 15 \\
\hline 99 & 1 & 5.6 & 16 \\
\hline 100 & 1 & 5.6 & 17 \\
\hline Totaal & 17 & 94.4 & \\
\hline Vermiste respondent & 1 & 5.6 & \\
\hline
\end{tabular}


Tabel 4: Die RAU as geheel: Vlakke van tevredenheid

\begin{tabular}{|l|l|l|l|}
\hline Vlak van tevredenheid & Frekwensie & Persentasie & Kummulatiewe frekwensie \\
\hline 70 & 1 & 5.6 & 1 \\
\hline 75 & 1 & 5.6 & 2 \\
\hline 80 & 5 & 27.8 & 7 \\
\hline 85 & 2 & 11.1 & 9 \\
\hline 86 & 1 & 5.6 & 10 \\
\hline 88 & 1 & 5.6 & 11 \\
\hline 90 & 4 & 22.2 & 15 \\
\hline 94 & 1 & 5.6 & 16 \\
\hline 95 & 1 & 5.6 & 17 \\
\hline Totaal & $\mathbf{1 7}$ & $\mathbf{9 4 . 4}$ & \\
\hline Vermiste respondent & 1 & 5.6 & \\
\hline
\end{tabular}

Vlakke van tevredenheid ten opsigte van potensiële beroepsmoontlikhede

Die laagste persentasie van student-tevredenheid ten opsigte van potensiële beroepsmoontlikhede was weer eens $60 \%$, soos aangedui deur Tabel 5 . Drie studente was $100 \%$ tevrede met hierdie aspek en ses studente was $90 \%$ tevrede, dit is $33.3 \%$ van die totale populasie.

Wanneer daar na bogenoemde statistiek gekyk word, blyk dit daar in studente se laerordebehoeftes voorsien is aangesien hulle tevredenheid ten opsigte van hoërordebehoeftes byvoorbeeld beroepsmoontlikhede, baie hoog is (Maslow, 1954).

Tabel 5: Beroepsmoontlikhede: Vlakke van tevredenheid

\begin{tabular}{|l|l|l|l|}
\hline Vlak van tevredenheid in \% & Frekwensie & Persentasie & Kumulatiewe frekwensie \\
\hline 60 & 2 & 11.1 & 2 \\
\hline 70 & 1 & 5.6 & 3 \\
\hline 80 & 2 & 11.1 & 5 \\
\hline 85 & 2 & 11.1 & 7 \\
\hline 90 & 6 & 33.3 & 13 \\
\hline 95 & 1 & 5.6 & 14 \\
\hline 100 & 3 & 16.7 & 17 \\
\hline Totaal & $\mathbf{1 7}$ & $\mathbf{9 4 . 4}$ & \\
\hline Vermiste respondent & 1 & 5.6 & \\
\hline
\end{tabular}


Die verband tussen tevredenheid en belangrikheid van die aspekte in die onderrigsisteem word vervolgens beskryf.

\section{Beskrywende statistiek ten opsigte van die studente se tevredenheid en belangrikheid ten opsigte van genoemde items}

Die tevredenheid en belangrikheid van elke item, is op ' $n$ skaal van 1 tot 7 aangedui. Die minimum kolom dui die minimum getal aan wat daar by die betrokke item deur die studente gemerk is. Die maksimum kolom dui die maksimum getal aan wat daar by die betrokke item deur die studente gemerk is. Tabel 6 weerspieël dat hoe groter die gaping tussen die minimum en die maksimum getalle was, hoe groter was die standaardafwyking. By die rekenaarfasiliteite, studentedienste, biblioteek en die individuele itemsessies was die populasie nie die volledige 18 studente nie (sien Tabel 6). Die rede hiervoor is dat daar op die vraelys by hierdie aspekte aangedui was dat indien die studente nog nooit van hierdie dienste gebruik gemaak het nie, hulle nie die betrokke vrae oor die item hoef te beantwoord het nie. Hierdie fasiliteite speel ' $n$ groot bydrae in onderriguitkomste en dit sou belangrik gewees het om die tevredenheid van studente in hierdie ondersteuningsdienste te kon bepaal om leemtes te kon identifiseer waar nodig.

\section{Korrelasie tussen belangrikheid en tevredenheid}

Korrelasie is dié mate waarin waardes van een veranderlike $(X)$, ooreenstem met die waardes van ' $n$ tweede veranderlike (Y) (Brink, 1999:207).

\section{Bespreking van die verband tussen studente-tevredenheid en belangrikheid}

In Tabel 6 word die beskrywende statistiek van die studente-tevredenheid en die belangrikheid van elke aspek uitgebeeld. Hiervolgens kan gesien word dat die gemiddelde tussen 1 en 7 van elke aspek tussen 5.5 -6.5 lê. Dit is 'n goeie bewys dat die vierdejaarstudente van die jaar 2001 oor die algemeen tevrede was met hulle kursus en die universiteitsmilieu as ' $n$ geheel. Daarom kan die afleiding gemaak word dat die regte dinge reg gedoen word by die universiteit (Vroeijenstein,
2001:5), anders sou daar nie so 'n hoë mate van tevredenheid onder die studente geheers het nie.

Volgens Tabel 7 word die korrelasie en die beduidendheid van elke aspek op die vraelys aangedui. Al die getalle in die korrelasiekolom wat 'n positiewe getal is, dui op positiewe korrelasies. Die getalle in die korrelasiekolom wat ' $n$ negatiewe getal is, dui op negatiewe korrelasies. (Tabel 7 is op bladsy 60 ).

Al die getalle in die beduidenheidskolom waarby daar ' $n$ agtergrond is, dui daarop dat die korrelasies beduidend is. Die getalle wat nie verklaar is nie, se waardes is so klein dat dit geen beduidenheid het nie. Getalle met hoë beduidendheidsvlakke, toon dat daar 'n goeie korrelasie tussen die tevredenheid en die belangrikheid van die betrokke aspekte is.

In Figuur 2 (op bladsy 61) kan die afstande tussen die verskillende aspekte ten opsigte van die tevredenheid en belangrikheid gesien word. Die aspekte wat nog aandag vereis is die Biblioteek (Tevredenheid $=5.104$, Belangrikheid $=6.55$ ), Studentesentrum (Tevredenheid $=4.865$, Belangrikheid $=6.66$ ), Studenteraad en Sosiale lewe (Tevredenheid $=4.802$, Belangrikheid $=$ 5.73), Studentedienste (Tevredenheid $=5.402$, Belangrikheid $=6.51$ ) en Rekenaarfasiliteite (Tevredenheid $=5.268$, Belangrikheid $=6.76$ ). By die res van die aspekte blyk dit dat die studentetevredenheid na aanleiding van die belangrikheid relatief hoog is. Daarom blyk dit dat daar aan die studente se verwagtinge en doelwitte voldoen word en dat die strukture, prosesse en uitkomste in die studente se omgewing bruikbaar is en die studente se behoeftes bevredig word (Fontenot et al. 1994:13).

Vanuit bogenoemde data en bespreking kan daar dus tot die gevolgtrekking gekom word dat B.Cur.finalejaarstudente van 2001, ' $n$ groot mate van tevredenheid ten opsigte van hulle program en die universiteitsomgewing beleef het.

\section{AANBEVELINGS}

Dit sou sinvol wees as ' $n$ soortgelyke studie met verdere jaargroepe van die B.Cur.-kursus uitgevoer word om so ' $n$ meer verteenwoordigende beeld te verkry van die B.Cur.-groep as geheel (eerstejaars tot vierdejaars) se tevredenheid. 
Tabel 6: Beskrywende statistiek ten opsigte van tevredenheid en belangrikheid

\begin{tabular}{|c|c|c|c|c|c|}
\hline & $\mathrm{N}$ & Min & Maks & Gemiddeld & SA \\
\hline KO \& A : Kommunikasie van inligting : T & 18 & 3.2 & 7 & 5.5472 & 0.8902 \\
\hline KO \& A : Kommunikasie van inligting : $\mathrm{B}$ & 18 & 5.6 & 7 & 6.6333 & 0.5053 \\
\hline KO \& A : Organisasie van die kursus : $T$ & 18 & 3.8 & 7 & 5.9111 & 0.8491 \\
\hline KO \& A : Organisasie van die kursus : $B$ & 18 & 5.6 & 7 & 6.5333 & 0.5179 \\
\hline $\mathrm{KO} \& \mathrm{~A}$ : Werklading en assessering : $\mathrm{T}$ & 18 & 4.09 & 7 & 5.7486 & 0.8131 \\
\hline $\mathrm{KO} \& \mathrm{~A}$ : Werklading en assessering : $\mathrm{B}$ & 18 & 5.18 & 7 & 6.3667 & 0.7127 \\
\hline KO \& A : Uitkomste van studie : $T$ & 18 & 4.57 & 7 & 6.3175 & 0.6418 \\
\hline KO \& A : Uitkomste van studie : $\mathrm{B}$ & 18 & 5.57 & 7 & 6.6746 & 0.4512 \\
\hline $\mathrm{O} \& \mathrm{~L}:$ Dosente : $\mathrm{T}$ & 18 & 5.4 & 7 & 6.3056 & 0.4709 \\
\hline $\mathrm{O} \& \mathrm{~L}:$ Dosente : B & 18 & 5.9 & 7 & 6.75 & 0.3959 \\
\hline $\mathrm{O} \& \mathrm{~L}:$ Onderrigsessies (Lesings/seminare) : $\mathrm{T}$ & 18 & 4.33 & 7 & 5.7778 & 0.8105 \\
\hline O \& L : Onderrigsessies (Lesings/seminare) : B & 18 & 4.83 & 7 & 6.463 & 0.668 \\
\hline $\mathrm{O} \& \mathrm{~L}$ : Individuele onderrig (Tutor + 1/2 studente): $T$ & 16 & 3.5 & 7 & 5.3437 & 1.2479 \\
\hline $\mathrm{O} \& \mathrm{~L}$ : Individuele onderrig (Tutor $+1 / 2$ studente): $\mathrm{B}$ & 16 & 3 & 7 & 5.9375 & 1.1955 \\
\hline O \& L : Praktiese sessies (Lab/ateljee/werkwinkel): T & 18 & 4 & 7 & 6.0222 & 0.9428 \\
\hline O \& L : Praktiese sessies (Lab/ateljee/werkwinkel): B & 18 & 5 & 7 & 6.6333 & 0.5667 \\
\hline $\mathrm{O} \& \mathrm{~L}:$ Werkervaring : $\mathrm{T}$ & 18 & 3.2 & 7 & 5.975 & 0.9201 \\
\hline $\mathrm{O} \& \mathrm{~L}:$ Werkervaring : $\mathrm{B}$ & 18 & 5 & 7 & 6.6556 & 0.5731 \\
\hline Die biblioteek : $\mathrm{T}$ & 17 & 2.5 & 6.25 & 5.1036 & 0.9858 \\
\hline Die biblioteek : B & 17 & 4.88 & 7 & 6.5529 & 0.6127 \\
\hline Rekenaarfasiliteite : $\mathrm{T}$ & 13 & 2.67 & 6.61 & 5.268 & 1.1283 \\
\hline Rekenaarfasiliteite : B & 13 & 6 & 7 & 6.7663 & 0.3394 \\
\hline Studentedienste : $\mathrm{T}$ & 17 & 3.87 & 6.44 & 5.402 & 0.7708 \\
\hline Studentedienste : B & 17 & 5.93 & 7 & 6.5152 & 0.4745 \\
\hline Die universiteitsomgewing : $\mathrm{T}$ & 18 & 4.48 & 6.71 & 5.7 & 0.5757 \\
\hline Die universiteitsomgewing : $\mathrm{B}$ & 18 & 5.52 & 7 & 6.6385 & 0.4861 \\
\hline Studentesentrum : $\mathrm{T}$ & 18 & 3.79 & 6 & 4.8651 & 0.6601 \\
\hline Studentesentrum : B & 18 & 5.36 & 7 & 6.6667 & 0.4918 \\
\hline
\end{tabular}




\begin{tabular}{|l|l|l|l|l|l|}
\hline & N & Min & Maks & Gemiddeld & SA \\
\hline Studenteraad en sosiale lewe : T & 18 & 2.64 & 6.64 & 4.8017 & 1.0353 \\
\hline Studenteraad en sosiale lewe : B & 18 & 3 & 7 & 5.7329 & 1.2333 \\
\hline Selfontwikkeling : T & 18 & 5.41 & 7 & 6.4216 & 0.5807 \\
\hline Selfontwikkeling : B & 18 & 5.94 & 7 & 6.7614 & 0.3904 \\
\hline
\end{tabular}

KO \& A: Kursusorganisering en Assessering

O \& L: Onderrig en Leer

T: $\quad$ Tevredenheid

B: Belangrikheid

Min: Minimum

Maks: Maksimum

SA: Standaardafwyking

Tabel 7: Beduidendheid tussen korrelasies van tevredenheid en belangrikheid

\begin{tabular}{|c|c|c|c|}
\hline & $\mathrm{N}$ & Korrelasie & Beduidenheid \\
\hline Kursusorganisering en assessering: Kommunikasie van inligting:T \& B & 18 & 0.509 & 0.031 \\
\hline Kursusorganisering en assessering: Kursusorganisasie: T \& B & 18 & 0.622 & 0.006 \\
\hline Kursusorganisering en assessering: Werklading \& assessering: T \& B & 18 & 0.75 & 0 \\
\hline Kursusorganisering en assessering: Uitkomste van studie: T \& B & 18 & 0.771 & 0 \\
\hline Onderrig en Leer: Dosente: T \& B & 18 & 0.497 & 0.036 \\
\hline Onderrig en Leer: Onderrigsessies (Lesings/seminare): T \& B & 18 & 0.485 & 0.041 \\
\hline Onderrig en Leer: Individuele onderrig (Tutor met $1 / 2$ studente): T \& B & 16 & 0.44 & 0.088 \\
\hline Onderrig en Leer: Praktiese sessies (Lab/ateljee/werkwinkels): T \& B & 18 & 0.589 & 0.01 \\
\hline Onderrig en Leer: Werkervaring: T \& B & 18 & 0.706 & 0.001 \\
\hline Die biblioteek: T \& B & 17 & -0.167 & 0.522 \\
\hline Rekenaarfasiliteite: T \& B & 13 & -0.088 & 0.775 \\
\hline Studentedienste: T \& B & 17 & 0.061 & 0.817 \\
\hline Die universiteitsomgewing: $T \& B$ & 18 & 0.484 & 0.042 \\
\hline Studentesentrum: T \& B & 18 & 0.287 & 0.248 \\
\hline Studenteraad en sosiale lewe: T \& B & 18 & 0.608 & 0.007 \\
\hline Selfontwikkeling: T \& B & 18 & 0.67 & 0.002 \\
\hline
\end{tabular}

T \& B: Tevredenheid en Belangrikheid 


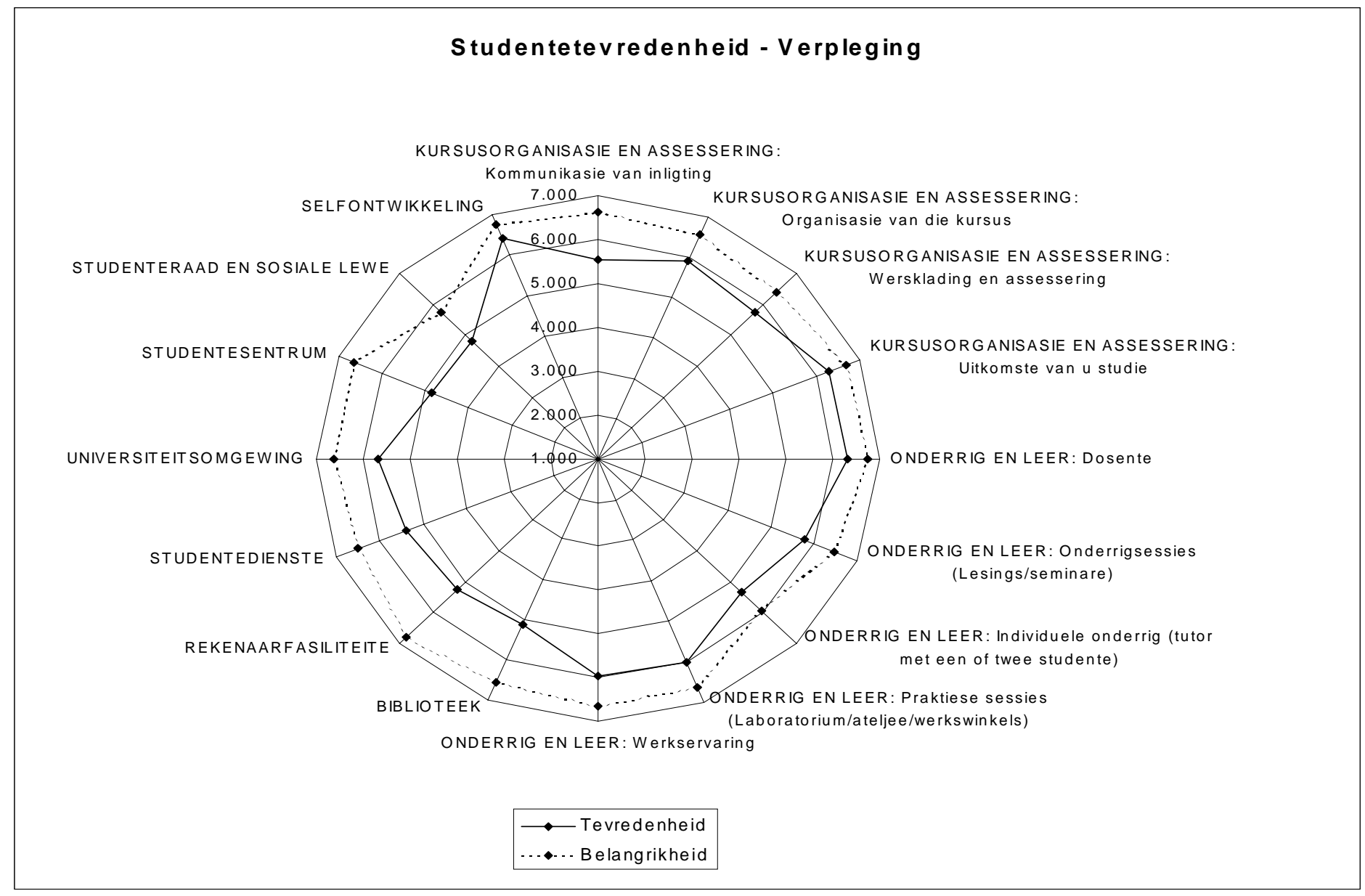

Figuur 2: Tekortontleding (gap analyses), grafiese voorstelling

Die aspekte op die tekortontleding waar die tevredenheid en belangrikheid na aan mekaar is, moet ook verder ondersoek word en hierdie positiewe terugvoering moet aan hierdie betrokke rolspelers oorgedra word. Die aspekte wat negatiewe terugvoering gekry het moet ondersoek word om sodoende verbetering by die betrokke rolspelers teweeg te bring.

Om die beperking van die studie ten opsigte van die steekproef of populasiegrootte aan te spreek, word daar aanbeveel dat daar gekyk word na die totale populasiegrootte van die volgende studentegroepe waarmee navorsingstudies in verband met studenttevredenheid gedoen gaan word. Dit sou dalk ook meer probleemaspekte van die universiteit as geheel uitbeeld.

\section{BIBLIOGRAFIE}

BEVIS, EMO 1978: Curriculum building in nursing: A process; $2^{\text {nd }}$ edition. St Louis: Mosby.

BRINK, HIL 1999: Fundamentals of research methodology for health care professionals; $2^{\text {nd }}$ edition. Cape Town: Creda Communications. DEPARTMENT OF HIGHER AND FUTHER EDUCATION 2001: National Plan for Higher Education 2001: Pretoria: Department of Higher and Futher Education.

FONTENOT, G; BEHARA, R \& GRESHAM, A 1994: Six sigma in customer satisfaction. Quality Progress, December: 73-76.

KOZIER, B; ERB, G; BLAIS, K \& WILKINSON, JM 1995:

Fundamentals of nursing: Concepts, process and practice; 5 th Edition. New York: Addison-Wesley.

LILIENFELD, R 1978: The rise of systems theory - An ideological analysis. New York: John Wiley.

MASLOW, AH 1954: Motivation and personality. New York: Harper. MULLER, M 1998: Nursing Dynamics; $2^{\text {nd }}$ edition. Cape Town: Heinemann.

MULLER, M 2001: Nursing Dynamics; 3rd edition. Sandton: Heinemann.

OLIVER, RL 1997: Satisfaction: A behavioral perspective on the customer; $1^{\text {st }}$ edition. New York: McGraw-Hill. 
RAU 2001: Etiese standaarde vir navorsing. Aucklandpark: Randse Afrikaanse Universiteit.

RAU, Departement Verpleegkunde 2001: Studiehandleiding, Verpleegkunde 4. Verpleegdinamika: Aucklandpark: Randse Afrikaanse Universiteit.

RAU, Departement Verpleegkunde 2002: Paradigma. Aucklandpark: Randse Afrikaanse Universiteit.

SAKO (Suid-Afrikaanse Kwalifikasie-Owerheid) 1997: 2(2), SAKO Bulletin, Uitvoerende beampte. Pretoria.

SAQA (South African Qualification Authority). 1997: 2(2), SAQA

Bulletin, Executive officer. Pretoria.

VROEIJENSTEIN AI 2001: Quality assurance, (Uitdeelstuk). Aucklandpark: Randse Afrikaanse Universiteit. 